\title{
ELIZAVETA POLUKHINA \\ EXTENDING THE SPACE OF DOMESTICITY \\ IN POST-SOVIET RUSSIA OR HOW THE DACHA IS TRANSFORMING INTO A SUBURBAN HOME IN MOSCOW REGION ${ }^{1}$
}

Elizaveta Polukhina, Associate Professor, Faculty of Social Sciences, HSE University, Russian Federation; off. 331, 11 Myasnitskaya Ulitsa, Moscow, 101000, Russian Federation.

E-mail:epolukhina@hse.ru

\section{Abstract}

This article describes the transformation of the ordinary Soviet dacha (a summer country house for urban families) into a suburban home suitable for year-round living. Based on interviews and observations in Moscow Region, the paper shows that the Soviet dacha was a place of labor with limited living space and, in postSoviet times, it progressively domesticated to a comfortable suburban home with comparatively limited labor practices. Thus, the contemporary dacha space is a second home and social institution for urban families with children as well as for retired people. An intersectional analysis shows that dacha residents are individuals who have the opportunity to be 'independent' from the city: retired people, children, and parents who work remotely. The data from an online focus group explain why this place is not an attractive for living among young adults (students) who strongly connected with urban practices and generally prefer an urban lifestyle. However, the image of the 'future home' for young adults is a cottage' or townhouse located close to the city. This means a close suburban home and a comfortable lifestyle could be a future trend even among adults in Moscow Region.

Key words: Soviet dacha; dacha space; domestication; second home; suburban home; post-Soviet Russia; family; remove job; suburban lifestyle

Citation: Polukhina E. (2018) Extending the Space of Domesticity in Post-Soviet Russia or How the Dacha is Transforming into a Suburban Home in Moscow Region. Urban Studies and Practices, vol. 3, no 4, pp. 152-163.

DOI: https://doi.org/10.17323/usp342018152-163

\section{The Russian Dacha: Origins and Purpose}

A dacha is a suburban house for summer-time living 2 and a unique phenomenon of Russian life. Dacha is a word derived from the Russian 'to give' which appeared in the $17^{\text {th }}$ century. The term 'dacha space' means the territory in which dacha communities and allotment associa-

1 The author acknowledges Pavel Lebedev for the help in fieldwork and 2 reviewers who gave fruitful comments and suggestions.

The article is prepared as a part of the project 'Past and Present of Working-Class Areas: Transformations of Sociocultural and Territorial Identities' supported by the Russian Foundation for Basic Research. Grant No. 1733-01006-OGN (http://present-past.ru/).

2 Generally, this phenomenon includes four main characteristics: 1) the dacha is a plot with a house 2) located outside the city 3) the owners are city dwellers 4) seasonable nature of usage, primarily during the warm season. 
tions are situated. This space can be seen schematically as a 'zone in the form of concentric circles radiating from downtown to the periphery' [Malinova-Tziafeta, 2013, p. 15].

Since the $17^{\text {th }}$ century, the physical form and location of the dacha has changed despite the continuity of the perception of the term. In the $17^{\text {th }}$ century, dachas were allocated by the state to aristocrats. In the beginning of the $19^{\text {th }}$ century, dachas were given to party officials and academics. At that time, having a dacha was a symbol of luxury and unattainable for ordinary citizens. A work entitled 'Our Nikolina Gora' [Chalykh, 2008] describes the dacha lifestyle of the intelligentsia with entertainment, body practices, and folklore.

In the 1950s, the meaning of the dacha changed and from an elite destination to became a mass phenomenon. ${ }^{3}$ Due to macroeconomic problems, plots of land were given to ordinary civil servants for self-sufficiency, with strict limits on construction. Opportunities for construction were limited, allowing cabins measuring only $2 \times 2$ meters. This was not a place for comfortable living, but a shed for weekend nights, or shelter from the rain in bad weather and called 'bytovka.' In Soviet times, the majority of dachas looked almost the same.

In the 1990s, when the Soviet planned economy finished, these plots were privatized, and land owners gained permission to build, as well as buy and sell. The typical dacha of that time was a wooden two-storey house with a mansard roof. The dacha was a source of produce; the main hobby for the majority of ordinary citizens. In the middle of the 1990s, $25 \%$ of families had a dacha, and one plot could belong to several families [Lovell, 2003]. The dacha was a 'safety net,' helping Russians to get through the crisis of the 1980s and 1990s [Ibid.]. By the end of the 20th century, dacha villages were an aspect of urban expansion [Tarakanov, 2007]. Spending summers at the dacha space became a part of affluent people's lifestyle [Ibid., p. 3]. The nature of the dacha then transformed to any type of suburban housing belonging to city dwellers [Ibid., p. 19]. Tarakanov considers the roles of industrial development and the deteriorating urban ecological situation in the popularization of dachas. He argues that the desire to live outside the city became popular and has turned dachas from an elite resource into a common one [Ibid., p. 20].

3 Some dachas continue to exist as elite estates [Averkieva, Nefedova, 2016].

\section{The similarity of Russian dachas practices to Western countries}

There are comparable dacha practices in Western Europe and North America. The closest resemblance is the 'schrebergarten' (plot of land). These spread at the beginning of the $20^{\text {th }}$ century in Germany. This was the renting of small plots by urban inhabitants. These plots formed huge colonies close to large German cities. 'Landhäuser' (rural houses) and 'sommer häuser' (summer houses), are also common in Germany. In France, similar houses are called 'maisons de campagne' (rural houses) or 'residences secondaires' (secondary houses) which are French vacation homes. In Britain, there are 'cottages,' sometimes called 'country cottages,' which means a house located outside the city in a rural area far from the city. The term 'cottage,' as well as its English nature, was inherited by Canadian culture [Harrison, 2013]. A familiar term is the 'summer house' in America. It is traditionally popular among professional middle classes in the United States [Balfe, 1995]. Generally, the main difference between the dacha and similar western practices is in the historical and cultural contexts of rural living.

\section{The Social Meanings of Dacha in the Post-Soviet Era}

'Summerfolk: A History of the Dacha, 17102000' [Lovell, 2003] revealed the dacha's multiple functions for the middle class, a way of overcoming urban frustrations, a space for intellectual communities, and a source for self-sufficiency. Lovell revealed the contradictory attitude to the Russian dacha; certain summerfolk despise and hate 'dachaness' as a lifestyle. He notes the ways in which Russian dachas differ from suburban Western European houses. The dacha expressed the polarity, inconsistency, and extremes in its perception. It seems to be a mirror of the Russian mentality and Russian society. The dacha includes a suggestive diversity in functional and economic status of housing (from brick-built villas to temporary constructions), sizes (from 2 decares to 1 hectare and more), inhabitants (government officials, intellectuals, and ordinary citizens), and occupation (it could be a luxury resort or a space of drudgery). Lovell concludes that the dacha can serve as a specific example of the mingling of modernization and traditionalism that has plausibly been seen as characteristic of the Soviet and other communist systems. It was valued as a symbol of material progress 
and for its association with civilized values (specifically, those of the officially-approved Russian intellectual tradition); but it also reflected the particularistic and personalistic realities of Soviet society [Lovell, 2003].

Galtz explores the dacha as a space of Foucault's heterotopias [Galtz, 2000], highlighting that contemporary bourgeois cottages 'celebrate the winners in the economic reformation' while denouncing the inability of others to succeed. She describes this space as a symbolic capital and a discourse area for the transit to the market economy, and a platform of social inequality [Ibid., p. 805]. It is as familiar as the spaces at cemeteries and villages. The heterotopia reconstructs the space in unexpected ways and offers new opportunities for body, time and pleasure. This theory assumes that these spaces are irregular and discretely developed. It focuses on subculture, hybrid, and differentiating issues [Ibid.].

Zavisca investigates the dacha based on its symbolism and discursive practices. She notes the harmonization of dachas in Soviet times where the main differences between dachas had to do with how much care one took of one's plot. Then the situation changed. Certain summerfolk started perceiving their dachas as a second job, however, she argues that the summerfolk identity is close to that of the peasantry. 'We manage to grow cucumbers! We are real summerfolk' [Zavisca, 2003, p. 797].

Work is a constant of dacha life. 'Only thieves don't work at the dacha,' one of Zavisca's informants said [Ibid., p. 789]. According to Zavisca's participant observation, this provides a way to speak about the morality and rationality of transiting to a market economy. The 'cottage' is a large dacha for super-rich 'new Russians,' a bourgeois house differs from a dacha due to the differences in social class and status. There is a huge historical gap between the dacha and the cottage. The cottage allows its owner to stay in a private zone.

The dacha phenomenon can arguably only exist coupled with the city. More than $40 \%$ of Russians have some kind of suburban home and $11 \%$ live in it all year-round [Levada Center, 2017]. In terms of Amin's and Thrift's approach, it can be described as a space of 'escape from the city' $^{4}$ where the urban resident senses a different pace and order of life [Amin, Thrift, 2002]. This 'escape from the city' is one of the main reasons

4 'Escapism opportunities' as the reasons for living at the second home were described by Chaplin [1999]. for being at the dacha. Malinova-Tziafeta describes the dacha as a space where "the middle class protects itself from the negative effects of urbanization and attempts to assert new values' [Malinova-Tziafeta, 2013, p. 215]. She emphasizes that the dacha provides the opportunity 'to find harmony with oneself and liberate oneself from false values' [Ibid., p. 200]. Alekseev explores the suggestion that dacha owners belong to different social classes and dacha practices are the core of Russian identity [Alekseev, 2016] - the dacha could be a source of solidarity in the current diverse Russian society.

We assume that places are not fixed, set forever and unchangeable but partly depend on the practices that happen there [Urry, 2007]. This paper focuses on current dacha spaces and practices and how they have changed from Soviet time. I show how Soviet dacha spaces and their meanings were adopted in the beginning of the 21st century in the post-Soviet Moscow Region.

\section{Empirical Data: Fieldwork and an Online Focus Group}

Fieldwork in the dacha space. The essence of the fieldwork is non-urban, where rural spaces are most adequate for data collection. Close living arrangements, high levels of social control, the density of social networks, and the visibility of the subjects increase the accessibility of informants in the dacha space. Moreover, our impression in the process of fieldwork was that some of the informants would not have been able to participate in research in an urban framework. This could be explained by the intensity of urban life, and the urban regime of communication with sociological structures.

The study was based on case-study methodology [Yin, 2014]. The selected case was a summer-plot association located near the town of Pushkino, approximately $30 \mathrm{~km}$ from Moscow along the Yaroslavl highway. The association includes approximately 175 plots, some of them allocated by the government in 1957 to people working in Moscow. Later, dachas were also allocated to Pushkino residents. There are currently suburban plots for sale in this association. The study was conducted from the summer of 2009 until 2011 [Polukhina, 2014]. We conducted participant observations with research dairies, a series of group interviews with families (7) and friends (4), and personal interviews (5) with dacha residents. My classmate was a gatekeeper who helped me to get access to informants. The 
sampling is purposive (dachniki) and based on the principal of maximum variation.

Online focus group with students. In order to test the hypothesis about rejection of dacha living by young adults, I conducted an online focus group with third-year bachelor's students. Our online discussion took place over 4 days in March 2014. The focus group participants included 12 students (10 females and 2 males) living in Moscow and having access to dachas (parents, grandparents). They actively discussed, on Vkontakte social network, their attitude to home and dacha, the opportunities and limits of dacha living, shared photos of their current housing conditions, their dachas and images of future dream homes.

\section{The Soviet Standard of the Dacha as Space for Work with Limited Living Opportunities}

The Soviet dacha differed considerably from the modern one. In the Soviet period, standards of living and strict rules were in place that regulated dacha activities. The purpose of the dacha was clearly emphasized; labor for the sake of the self-production of goods for personal consumption. The rules of dacha life were clearly defined and strictly controlled by the association management and neighbors. This was called the 'collective eye' phenomenon [Lovell, 2002, p. 119]. The informants remembered:

If you didn't plant things they took your plot away! They would come, the chairman would inspect that there's not a single [unauthorized] blade of grass $\langle\ldots\rangle$ building large houses was not allowed. You couldn't build toilets or saunas. You couldn't keep your car on the plot, because the whole plot had to be planted over. The best crops were sent to competitions. (male, 65 y.o.)

A person at the dacha during Soviet-time was visible, exposed, controllable and solid fences were rare. Urban residents' free time was dedicated to a new form of labor. An individual almost never left the labor collective and what was previously private (apartment) life became collective (dacha) life. This type of housing is familiar to Soviet people who were used to living in communal flats. As a place of work, the dacha community reproduced Soviet-era industry norms. As such, the Soviet dacha was a kind of production department, a counterpart of the kolkhoz or 'garden settlements,' 'collective farms for under-provisioned urbanites, as openair communal flats' [Ibid., p. 119] where collective labor was the central mission. The collective can be understood as a group of neighboring colleagues of the same dacha association, and in the stricter sense of family-dacha labor.

\section{Was the Dacha Work Inefficient or what was the Dacha's 'Passion'?}

In post-Soviet times the dacha culture embodies a particular lifestyle, including a number of practices related to that space. The first among them is the Soviet determined tradition of dacha labor, which is close in its meaning to a special sort of leisure activity 'dacha passion.' The informants' statements corroborate the ambivalence todacha labor as a phenomenon which generates a multiple-meaning continuum between labor as a 'burden' and a unique leisure activity:

Do you think I'd do it if I didn't like it? (wife, 58 y.o.)

This is a way of life. (husband, 61 y.o.)

I get pleasure from it, from this work! (wife, 58 y.o.)

The dacha provides opportunities for special forms of recreation, bathing, picking mushrooms or berries, participating in rituals such as evening tea parties with a samovar, or listening to music. The dachnik's appearance is different from a typical urban resident's look. The process of changing into 'dacha clothes' per se means a translocation into a space with different rules, culture, and rhythm of life: 'Don't take pictures of us, we're here in these, in dacha clothes...' (female, 67 y.o.)

The dachniki, or summerfolk are those who possess a dacha, i.e., a plot with a house for an urban family's stay, primarily in the summer. Formal ownership of a dacha does not automatically turn urbanites into summerfolk. What makes them summerfolk is their being engaged in the corresponding practices and upholding the informal but extant rules that define the dacha as a space with a specific social order, system of relationships, and 'rules' determining the participants' interactions. One's level of engagement and intensity of participation in dacha practices indicates whether one belongs to the group and allows for such labels as 'real dachniki' and 'not dachniki' [Zavisca, 2003]. The informal rules of the dacha culture are mainly upheld by the older generation [Bochardt, 2007, p. 9].

Some activities in the dacha space include special passions and cultural hobbies. These activities are the core of the summerfolk's solidarity and identities [Ibid., p. 7-8]. Researchers have developed this idea and established that working at 
the dacha is inefficient [Chekhovskih, 2001] since it is cheaper to buy vegetables than to grow them. However, it is a family strategy for self-sufficiency in periods of economic crises [Clarke et al., 2000; Ekström, Ekström et al., 2003]. The 'urban peasant' myth has been debunked [Clarke et al., 2000]. Sociologists have investigated large quantities of statistical data on Russian households (RLMS) and discovered the main characteristics. While well-off people use the dacha mostly for recreation, its main function for the disadvantaged is producing food for self-sufficiency [Ries, 2009; Gerry, Li, 2010; Southworth, 2006]. ${ }^{6}$ Typical dacha residents are retired people and those close to retirement age [Clarke et al., 2000, p. 548]. This has changed the employment structure among elderly citizens. They aim to be retirees as soon as possible. This change happens because they desire to spend more time in the dacha space [Chekhovskih, 1998, p. 27]. Generally, the most significant variables determining the attitudes towards the dacha are: income, age, being a parent, and education. Therefore, more-educated people are more motivated to have a dacha. Children, in particular, are significant drivers for domesticating this space [Clarke et al., 2000, p. 485]. Certain residents prefer dacha vegetables because they are organic. It is this concern for food quality which is an attribute of the well-educated parents of young children.

The plot is often easily observed by neighbors who unconsciously evaluate the plot's state. It is not respectable to be a lazy dachnik and they have to cultivate. As a result, social control is expressed through competition and creativity [Bochardt, 2007, p. 9].

We plant from time to time, for the neighbors. Otherwise we would be embarrassed in front of them for not growing anything. (female, 45 y.o.)

The neighbors act as social inspectors surreptitiously prompting one another to work on the plots and renovate the houses. 'It is here that the owners' diligence and their life success is being assessed based on the state of their dacha' [Chekhovskikh, 2001, p. 82]. Work as a summerfolk's value is not only looking to one's

5 According to Ekström et al. [2003], in order to cope with changes in society related to economic reforms, Russian households changed both their food consumption and food production patterns. There was no big difference between urban and rural households. Nearly all of the households were self-sufficient in the provision of vegetables and potatoes. Many households had a 'dacha', plot, where they produced most of what they needed.

6 For example, anthropologist Nancy Ries [Ries, 2009] has shown that 'potatoes' are a key subsistence element throughout postsocialist countries. neighbors, but also encouraging contact among them, in the creation of social relationships. To consult one another on gardening or to go shopping together for gardening equipment at the closest market are daily social interactions. A particularly widespread and honored ritual is to treat one's neighbors to vegetables or fruit from one's own garden.

The requirement to work at the dacha is an important 'hidden' rule. It is based on culture and history, and is at the core of the 'dachnik' identity. The tradition of working at the dacha is passed from the older to the younger generations. Despite the fact that the dacha is gradually becoming a resort environment, the older generation insists on the need for labor. For older people, summer work as 'dacha passion' a source of self-confidence, pride, and self-esteem.

\section{The Dacha Space Requires Men's Labor or 'Masculine Domesticity"7}

Some summerfolk build additional structures adjoining or near their houses. Now larger 'warm' houses (equipped with heating systems) are built, replacing smaller cabins or sheds. The role of the construction work on the plot grows, and the need for 'male' labor grows in demand.

$\mathrm{He}$ [the nephew] does in our family what several men should be doing. We don't let him go; he helps around the house, with building. We couldn't do without him here. (female, 62 y.o.)

Female families ${ }^{8}$ invite male neighbors or guests from the city to perform 'male' duties. Male physical labor is particularly needed at the dacha. There are construction brigades in dacha settlements who perform such physical work for money. The brigades are largely made up of migrant workers who live on the same plots they are working on. However, not many men can afford to hire them, and gladly work themselves. Male summerfolk find their calling in construction tasks such as digging a well, or building a sauna, a house, or a doghouse. It should be noted that construction at the dacha is a highly rational form of labor in terms of current prices and an investment in the plot. In some cases, minimal building changes on the plot allows the owner to sell it afterwards at a price several times higher than the initial price paid.

For some male summerfolk, building is not about the result; they are happy with an ongoing construction situation, and enjoy the process. 'Here I can do anything; in the apartment I can do

7 For more about this term, see [Marsh, 1988].

8 Families without man/ adult male. 
nothing.' (male, 65 y.o.) As a result, construction work as an opportunity to display masculinity makes the dacha an attractive place. This is a space of legitimate masculinity where it is possible to "build a house, bring up a son and plant a tree. ${ }^{9}$ Marsh [1988] explain this aspect of gender-legitimatization as 'masculine domesticity.'

\section{Retirees and Children as Dacha Residents}

Modern cities tend to exclude certain social groups. This mainly concerns unemployable urbanites, retirees and children. These are interconnected groups and typical participants in dacha interactions. The dacha is the second most popular place of summer recreation (after the primary home) for retirees between 56 and 60 years old (28\%) [Press release, 2013].

The gendered division of labor is one of the informal rules of dacha life. In this space, women, mostly grandmothers, engage in housework and childrearing: I sit here at the dacha, I've brought up my kids, now I'm looking after my grandkids. (female, 55 y.o.)

Cities exclude children, turning them into a marginalized generational group, and placing them on the same level as the disabled [Matthews, Limb, 1999]. The dacha allows particular practices of children's leisure which differ from those in the city, and serves as a platform for their education:

Children who grew up at the dacha, they don't screw around, they read a lot, nap time is required like at [summer] camp. And if you don't sleep - you have to read! (male, 31 y.o.)

This space and the presence of significant adults determine a 'natural' daily routine for the children - sleeping, eating, reading, being in the open air, and exercising [Shmerlina, 2007, p. 26]. In the dacha space, generations of children have been formed. 'It is in childhood that the territorial parameters of establishing friendship ties prevail and one can be friends, i.e. communicate with others, all day long' [Ibid., p. 42]. Because a child does not possess a clear vision of the social world and its structure, 'dacha friends' can be children from completely different classes and social groups. Despite the fact that dacha communities were historically formed as homogeneous associations (according to professional principles), differentiation is occurring.

9 This is a traditional Georgian proverb which is popular in Russia. It is perceived as showing the main men's duties.

\section{Why Young People are not Dacha Residents: the Results of an Online Focus-group}

Young people who have already grown out of 'dacha childhood' but do not yet have children of their own tend to visit the dacha less often.

Three or four days in nature are enough for me. I could never live in a dacha. The city gives me strength. Without this rush I can die. At the dacha I'm only with my friends at the banya, poker, barbecues, booze. (young adult, male, 20 y.o.)

They mainly go there with group of urban friends or colleagues for recreation, such as swimming, sunbathing, and barbecues. This group is the least involved in dacha practices due to their activity in urban leisure, education$\mathrm{al}$, or working life.

I could not live at the dacha, too troublesome and not equipped enough. Plus, it's inconvenient to get to everything - work, study, bars, friends. (young adult, female, 22 y.o.)

Remarkably, their dream home is a suburban house, not an urban flat.

I dream about a small two-storey house with green lawns and swings in the backyard. (young adult, female, 20 y.o.)

These young adults did realize that an equipped suburban life in a comfortable home requires a lot of expense. They explained their desire to have a suburban house because 'it promotes a healthy lifestyle. In this case, the ideal option would be remote working' (young adult, female, 21 y.o.). The males of our focus-group were more frugal in their housing plans and preferred not to deal with the hardship of suburban housing and communal services; females were more motivated for suburban life in the future.

I would like, in the future, to live in a separate house, like many of us. The house itself will be spacious, two floors and an attic. In such a house it would be optimal to live and work. The internet is a great thing. (young adult, female, 20 y.o.)

For young adults, continually being in the city is important and this group forms the stable class of urbanites. They regard the dacha as a space of consumption and leisure/pleasure activities [McReynolds, 2003, p. 3-6]. However, the 'family cycle' will eventually make them engage in the dacha or suburban life more fully.

\section{The Domestication of the Dacha Space, Life Cycle and Family in Post-Soviet Russia}

The dacha is a family phenomenon, 'an embodiment of an awakening domesticity' [Lovell, 2002, p. 118]. When informants talk about their neigh- 
bors and their neighbors' plots, it is implied that the plots are inhabited by families. This can be explained historically based on the Soviet past. 'Maintaining and supporting the garden was hard physical labor requiring the participation of several people. In families, parents steered children towards this work and when the children grew up, they, in turn, brought their own children into the garden' [Chekhovskikh, 2001, p. 78]. Having a dacha is considerably harder for single people. A family cycle is reproduced at the dacha where parents teach their children to work; the children grow up, create their own families, bring their wives/husbands to the plot, rear children, and teach them the same [Ibid., $p$. 79]. Historically, the dacha reinforces the creation of a classical family in order to confirm with the social order of that space.

Social researchers describe the current dacha situation as follows: 'The owners come to their secondary houses during the warm season, on weekends and holidays only. The dacha owners' preferred activities $<\ldots>$ include relaxing, tending plants, renovating their houses and [barbecuing]' [Public Opinion Foundation, 2013]. On the whole, and in the most general sense, today's dacha is primarily a seasonable hobby and a summer getaway. It also incorporates the meaning of a second house. It allows for the extension of the space of the primary home and compensates for the lack of private space in a small apartment. The problem of space has been acute for Moscow residents since Soviet times. For instance, $61 \%$ of Russians stated that their families needed to improve their housing conditions and only $10 \%$ had the wherewithal for that [Public Opinion Foundation, 2014].

Dachas form stable neighborhood communities. Stable neighborhood relationships are a prerequisite for the successful development of local territories [Berg, Nycander, 1997]. This space encourages neighbors to engage in social relations. Neighbors help each other with security issues, transport, construction, and other daily tasks. Health issues are traditionally resolved through self-organization. For instance, in the observed community, there was only one doctor (he was one of the residents and was not allowed to work in the community officially) for 175 dwellings. Neighbors in the modern dacha space engage in common recreational rituals, such as tea parties, celebrations, birthdaysand weddings. The fact that dachas were allocated to professionals means that the members of any given dacha community tend to have similar social backgrounds and, as a consequence, a lifestyle that is familiar to other members of the community.
The dacha has considerable potential as an element of the sustainable social development for urban residents. Based on Colantonio and Dixon's [2009] definition, social development concerns how individuals, communities and societies live with each other and set out to achieve the objectives of development models which they have chosen for themselves, taking into account the physical boundaries of their places and planet as a whole. At a more operational level, social sustainability stems from actions in key thematic areas, encompassing the social realm of individuals and societies, which range from skill development to environmental and spatial inequalities [Ibid.]. According to Inglehart's theory of the postmaterialist shift in Western industrialized societies, economic growth and development are accompanied by changes in the value structure; postmaterialist values, such as good ecological conditions and good health, have become more important than materialist ones, such as apartments, cars, and summer houses [Inglehart, Wetzel, 2008].

The dacha remains an object linked to postmaterialist values whose significance, according to Inglehart's theory, is likely to increase in the future. Several centuries ago, the dacha was considered a place for improving urban residents' health; 'urban citizens believed that out-oftown summer holidays improved their mental as well as physical health' [Malinova-Tziafeta, 2013, p. 158]. More educated people are more likely to be motivated to have a dacha. Children, in particular, are significant drivers for domesticating this space [Clarke et al., 2000, p. 485].

The dacha community exhibits a complex social structure which can be explained by the concept of a social institution, an element of the organizational structure of society, that is, specific mechanisms of social life providing stability for the social system and its development. It has a long history of helping to maintain the social balance depending on the stage of the family cycle, age, gender, life style, etc.

The contemporary dacha provides an opportunity for family development in terms of bringing up children, gender regimes, the order of domestic labor, leisure, and neighborhood relationships. Cities are unfit for children who prefer to spend time at the dacha. The dacha space and its 'significant adults' determine a 'natural' schedule including sleeping, eating, reading and outdoor exercise. Time spent at the dacha, unlike that spent in the big city, is considered 'natural' [Shmerlina, 2007]. 
Table 1. How dacha spaces, practices and meanings historically transformed

\begin{tabular}{||l||l|l|l|l||}
\hline Historical periods & $\begin{array}{l}\text { Dominant } \\
\text { characteristics of the } \\
\text { dacha space }\end{array}$ & $\begin{array}{l}\text { Meaning and } \\
\text { practices of usage }\end{array}$ & Residents & $\begin{array}{l}\text { Structural } \\
\text { characteristics }\end{array}$ \\
\hline \hline $17^{\text {th }}-19^{\text {th }}$ centuries & $\begin{array}{l}\text { Spacious wooden } \\
\text { house for relaxation } \\
\text { in the summer, } \\
\text { mostly with help of } \\
\text { domestic workers }\end{array}$ & $\begin{array}{l}\text { A symbol of luxury, } \\
\text { not for ordinary } \\
\text { citizens }\end{array}$ & $\begin{array}{l}\text { Elite part of the } \\
\text { Russian Empire } \\
\text { (officials, academics, } \\
\text { intellectuals) }\end{array}$ & $\begin{array}{l}\text { Extended territories } \\
\text { centered around } \\
\text { St. Petersburg and } \\
\text { a strict class system }\end{array}$ \\
\hline 1950 's - 1991 & $\begin{array}{l}\text { Plots of land } \\
\text { with strict limits } \\
\text { on building } \\
\text { construction, cabins } \\
\text { 2×2 square meters }\end{array}$ & $\begin{array}{l}\text { Mass phenomenon, } \\
\text { for self- } \\
\text { sufficiency during } \\
\text { macroeconomic } \\
\text { problems (gardening) }\end{array}$ & $\begin{array}{l}\text { Ordinary civil } \\
\text { servants }\end{array}$ & $\begin{array}{l}\text { Soviet Russia with } \\
\text { center in Moscow } \\
\text { and strict social class } \\
\text { system }\end{array}$ \\
\hline $\begin{array}{l}\text { Privatized plots for } \\
\text { summer, seasonal or } \\
\text { year-round living }\end{array}$ & $\begin{array}{l}\text { Suburban home } \\
\text { with a mix of } \\
\text { suburban (vegetable } \\
\text { gardening, relaxing } \\
\text { in the air and } \\
\text { wood, swimming) } \\
\text { and urban (remote } \\
\text { employment, wage } \\
\text { workers) practices }\end{array}$ & $\begin{array}{l}\text { Popular among } \\
\text { different social } \\
\text { classes }\end{array}$ & $\begin{array}{l}\text { Post-Soviet Russia } \\
\text { with no strict social } \\
\text { class system, reduced } \\
\text { quality and the } \\
\text { high cost of living } \\
\text { in cities, remote } \\
\text { working, opportunity } \\
\text { to have and live in } \\
\text { two homes (flat and } \\
\text { suburban house) }\end{array}$ \\
\hline
\end{tabular}

The traditional gender order is maintained..$^{10}$ Men explore the physical space and do physical work while women cook and look after children. However, in contrast to traditional urban practices at the dacha, women are involved in gardening activities, while men are involved in construction and home improvement. This fact gives the impression that these practices, having been historically rooted, live in close proximity to the earth, are now becoming difficult or almost lost. Arguably, this division of labor is the essence of dacha 'passion.' These practices are now reappearing and close to postmaterial values. The range of gendered practices creates a 'positive' gender regime where women realize their creativity and esthetic aspirations in gardening, and men are offered a version of a legitimate masculinity in the form of self-fulfillment through construction work.

\section{Conclusions and Discussions}

In the context of post-Soviet Moscow, the meaning and form of the dacha is slowly transforming from a summer house into year-round

10 Current dacha's practices are slowly demonstrating the rejection of the strict structure of gender defined work, which has been facilitated by involvement of an immigrant workforce and others contemporary novelties. accommodation. Dacha residents are socializing and improving the conditions there, while their city boundaries are expanding. The dacha space includes suburban as well as urban facilities associated with a comfortable life, such as gas, internet access, remote working, and wellstocked shops. As Giddens suggests, improving communication technology allows people to live far from work. This work comes to them because new production is mainly located away from the city [Giddens, 1999, p. 503]. Therefore the dacha space gives its inhabitants freedom from the urbanized pace of life, with its own domesticated social order [Pouching, 2014, p. 22].

Trends in the 21 st century demonstrate suburbanization as a process where citizens prefer to live outside the city or to have a second home and the associated life style [RLMS, 2017]. A similar tendency of suburbanization is taking place in some global cities, for example, New York with its extended living areas in the suburbs. Contemporary dachas are transforming into 'suburban homes' suitable for year-round living. This tendency has been mentioned by previous researchers. For example, Struyk and Angelicifind that some dachas are being converted and added to the permanent housing stock [Struyk, Angelici, 1996], while Rose and Tikhomirov [1993] note the proliferation of satellite cities and the conversion of seasonal dachas 
into full-time residences. This, however, refers mostly to 'close dachas' with a well-organized infrastructure and transport connections with the main city. Thus Struyk and Angelici [1996] based their conclusions on a case study of 'Rublevka,' a luxury area near the city of Moscow around the Rublevo-Uspenskoe highway. A 2015 law allows one's dacha to be officially registered as one's place of residence. Due to this change, sustainable neighborhoods were formed. Some suburban infrastructure developed rapidly, gas became available, roads were built or improved, and service industries were established. Significant numbers of citizens are involved in remote employment and have the opportunity to visit the office/city once or twice a week [Strebkov, Shevchuk, 2012]. Moscow is cramped and, as a

\section{References}

Alekseev M. (2016) Dacha - russkaya natsional'naya mechta [Dacha - Russian national dream]. Available at: https://esquire.ru/articles/8692-alekseevsky/\#part2 (accessed 13 September 2018). (in Russian)

Amin A., Thrift N. (2000) Cities: Reimagining the Urban. Cambridge: Polity.

Averkieva K., Nefedova T. (2016) Dachas and the Colonization of Rural Areas by Urban Citizens in Russia: The Case of the Kostroma Region, Mir Rossii, vol. 25, no 1, pp. 103-128. (in Russian)

Balfe J.H. (1995) The Inheritance of Summer Houses and Cultural Identity. The American Sociologist, vol. 26, no 4, pp. 29-40.

Berg P.G., Nycander G. (1997) Sustainable neighbourhoods - a qualitative model for resource management in communities. Landscape and Urban Planning, no 39, pp. 117-135.

Bochardt I. (2007) Seasonal leisure spaces: dachas in Western Siberia. Culture, pp. 8-10.

Chalykh N. (ed.) (2008) Nasha Nikolina Gora [Our Nikolina Gora], vol. 2. Moscow. (in Russian)

Chaplin D. (1999) Consuming work/productive leisure: the consumption patterns of second home environments. Leisure Studies, vol. 18, no 1, pp. 41-55.

Chekhovskih I. (1998) Novyye rynochnyye strategii molodozhi v neformal'noy ekonomike [New marketing strategies of youth in the informal economy]. Young Russia: a lost generation or the hope of the XXI century? Yuvenologicheskaya Russian Scientific and Practical Conference. Moscow. (in Russian)

Chekhovskikh I. (2001) Rossiyskaya dacha - suburbanizatsiya ili ruralizatsiya? [Russian dacha: suburban- result, some dacha residents stay in the suburbs during cold periods. This phenomenon is mainly the result of reduced standards and of the high cost of living in Moscow and other cities, plus the attraction of a suburban lifestyle.

Standards and norms of living spaces regulate social life and the position of individuals. In Soviet times urbanities felt 'confined' by the standard limited dacha space and the strict rules for its use. In the planned economy, the standard of dacha was mainly designed for people's self-sufficiency and it was unified and state-controlled. The daily life and practices of the Soviet people were regulated by social policies. In the post-soviet economy owners have step-by-step domesticated the dacha space and prefer the suburban home as new habitat norm.

ization or ruralization?]. Center of Independent So cial Research. Saint Petersburg. Available at: http:// www.cisr.pro/files/old/sbornik9/9_chekh.htm (accessed 6 September 2018). (in Russian)

Clarke S. et al. (2000) The Myth of the Urban Peasant. Work, Employment and Society, no 14, pp. 481-499.

Colantonio A., Dixon T. (2009) Measuring Socially Sustainable Urban Regeneration in Europe, Oxford Institute for Sustainable Development.

Dominanty Project (2012). FOMnibus Survey. Public Opinion Foundation. Available at: http://fom.ru/Rabota-idom/10432 (accessed 6 September 2018).

Ekström K.M., Ekström M.P., Potapova M., Shanahan H. (2003) Changes in food provision in Russian households experiencing perestroika. International Journal of Consumer Studies, vol. 27, no 4, pp. 294-301.

Galtz N. (2000) Other Spaces and Everyday Ones: Promise and limits of Foucault's heterotopia for the study of everyday life.

Gerry C.J., Li C.A. (2010) Consumption smoothing and vulnerability in Russia. Applied Economics, vol. 42, no 16, pp. 1995-2007.

Giddens A. (1999) Runaway World: How Globalization is Reshaping Our Lives. London.

Harrison J. (2013) A timeless place: the Ontario cottage. UBC Press.

Inglehart R., Wetzel C. (2008) Changing Mass Priorities: The Link between Modernization and Democracy. Perspective on politics, vol. 8, no 2, pp. 551-567.

Levada Center (2017). Dacha i domashniye zagotovki [Dacha and home preparations]. Available at: https:// www.levada.ru/2017/10/25/16909/(accessed 6 September 2018). (in Russian) 
Lovell S. (2002) Soviet Exurbia: Dachas in Postwar Russia. Socialist spaces: sites of Everyday life in Eastern Bloc / D. Crowley, S. Reid, E. Berg (eds), pp. 105-120.

Lovell S. (2003) 'Summerfolk: A History of the Dacha, 1710-2000.' Moscow. Academicals Project.

Malinova-Tziafeta O. (2013) Iz goroda na dachu: sotsiokul'turnyye protsessy osvoyeniya dachnogo prostranstva vokrug Peterburga (1860-1914) [From the city to the dacha: Socio-cultural factors of the dacha space assimilation around Saint-Petersburg (18601914)]. Saint-Petersburg: European University of Saint-Petersburg Publishing. (in Russian)

Marsh M. (1988) Suburban Men and Masculine Domesticity, 1870-1915. American Quarterly, vol. 40, no 2, pp. 165-186.

Matthews H., Limb M. (1999) Defining an Agenda for the Geography of Children. Progress in Human Geography, vol. 23. no 1, pp. 61-90.

McReynolds L. (2003) Russia at Play: Leisure Activities at the End of the Tsarist Era. Ithaca, NY: London: Cornell University Press.

Polukhina E. (2014) Osobennosti sotsial'nogo poryadka $\checkmark$ postsovetskom dachnom prostranstve: trud, gene i gender [The particular of social order in the space of post-Soviet dacha: work, generations and gender]. Labyrint, vol. 3, pp. 22-31. (in Russian)

Press release no 2416 (2013). Pozhilyye rossiyane: sotsial'noye samochuvstviye i obraz zhizni [Elderly Russians: Social Well-Being and Lifestyle]. The All-Russian Public Opinion Research Center: official website. Available at: http://wciom.ru (accessed 6 September 2018). (in Russian)

Public Opinion Foundation (2007). Official website. All-Russian population survey. June 9-10. 100 settlements, 44 subnational entities of the Russian Federation, 1500 respondents. Available at: http:// bd.fom.ru/report/map/d072425 (accessed 6 September 2018). (in Russian)
Public Opinion Foundation (2013). On Dachas and Dacha Residents. Official website. Available at: http:// fom.ru/Rabota-i-dom/11029 (accessed 6 September 2018). (in Russian)

Ries N. (2009) Potato Ontology: Surviving Postsocialism in Russia. Cultural Anthropology, vol. 24, no 2, pp. 181-212.

RLMS (2017) The Russian Longitudinal Monitoring Survey - Higher School of Economics (RLMS - HSE). Available at: https://iq.hse.ru/news/212804422.html (accessed 6 September 2018). (in Russian)

Rose R., Tikhomirov E. (1993) Who Grows Food in Russia and Eastern Europe? Post Soviet Geography, vol. 34, no 2, pp. 111-126.

Shmerlina I. (2007) Svobodnoye vremya - navyazannoye prostranstvo zhizni? Free time: an imposed space of life? Sotsial'naya real'nost' [Social Reality], no 8, pp. 6-31. (in Russian)

Southworth C. (2006) The Dacha Debate: Household Agriculture and Labor Markets in Post-Socialist Russia. Rural Sociology, vol. 71, no 3, pp. 451-478.

Strebkov D., Shevchuk A. (2012) Electronic Self-Employment in Russia. Problems of Economic Transition, vol. 55, no 5, pp. 76-97.

Struyk R.J., Angelici K. (1996) The Russian dacha phenomenon. Housing Studies, vol. 11, no 2, pp. 233-250.

Tarakanov D. (2007) Dachnyye poselki Podmoskov'ya $v$ kontse XIX - nachale XX veka [Dacha townships in localities near Moscow in the late XIX and early XX century]. Author's abstract of the doctoral thesis in historical sciences. (in Russian)

Urry J. (2007) Mobilities. Cambridge: Polity.

Yin R.K. (2014) Case Study Research. Design and Methods. Fifth Edition. SAGE Publications.

Zavisca J. (2003) Contesting Capitalism at the Post-Soviet Dacha: The Meaning of Food Cultivation for Urban. Slavic Review, vol. 62, no 4, pp. 786-810. 


\title{
Е.В.ПОЛУХИНА
}

\section{РАСШИРЕНИЕ ДОМАШНЕГО ПРОСТРАНСТВА В ПОСТСОВЕТСКОЙ РОССИИ,}

\author{
ИЛИ КАК ДАЧА В МОСКОВСКОМ РЕГИОНЕ ТРАНСФОРМИРУЕТСЯ \\ В ЗАГОРОДНЫЙ ДОМ
}

Полухина Елизавета Валерьевна, доцент департамента социологии НИУ ВШЭ; Российская Федерация, 101000, Москва, ул. Мясницкая, д. 11, каб. 331.

E-mail:epolukhina@hse.ru

В статье описывается трансформация пространства традиционной советской дачи в загородный дом, подходящий для круглогодичного проживания. Интервью и наблюдения, проведенные в Московском регионе, позволяют сделать вывод, что советская дача была местом труда с незначительным пространством для жизни, а в постсоветское время она постепенно преобразовалась в полноценный загородный дом, сократив значение трудовых практик и пространств. Таким образом, современное дачное пространство - это второй дом горожанина и социальный институт как для городских семей с детьми, так и для пенсионеров. Интерсекциональный анализ показывает, что жители дачи - это люди, которые имеют возможность быть «независимыми» от города: пенсионеры, дети и родители, работающие удаленно. Данные онлайн-фокус-группы объясняют, почему молодых людей (студентов), которые тесно связаны с городскими практиками и обычно предпочитают городской образ жизни, дача как место проживания не привлекает. Однако образом «будущего дома» для молодых людей является «коттедж» или таунхаус, расположенный недалеко от города. Это означает, что загородный дом и комфортный образ жизни могут стать трендом даже среди взрослого населения Московской области.

Ключевые слова: советская дача; дачное пространство; второй дом; загородный дом; постсоветская Россия; семья; удаленная работа; загородный образ жизни

Цитирование: Полухина Е.В. (2018) Расширение домашнего пространства в постсоветской России, или как дача в московском регионе трансформируется в загородный дом. Urban Studies and Practices, vol. 3, no 4, pp. 152-163 (на англ. яз.)

DOI: https://doi.org/10.17323/usp342018152-163

\section{Источники}

Аверкиева К.В., Нефедова Т.Г. (2016) Дачная «колонизация» российской глубинки. Пример Костромской области // Мир России. Т. 25. № 1. С. 103-128.

Алексеев М. (2016) Дача - русская национальная мечта. Режим доступа: https://esquire.ru/articles/8692alekseevsky/\#part2 (дата обращения: 13.09.2018).

Малинова-Тзиафета О. (2013) Из города на дачу: социокультурные процессы освоения дачного пространства вокруг Петербурга (1860-1914). СПб.: Изд-во Европейского ун-та.

Полухина Е. (2014) Особенности социального порядка в постсоветском дачном пространстве: труд, поколения и гендер // Лабиринт. Т. 3. С. 22-31.
Чалых Н. (ред.) (2008) Наша Николина Гора. Кн. 2. Москва.

Чеховских И.А. (1998) Новые рыночные стратегии молодежи в неформальной экономике. Молодая Россия: потерянное поколение или надежда XXI века? Российская ювенологическая научно-практическая конференция. Москва.

Чеховских И.А. (2001) Российская дача - субурбанизация или рурализация / Центр независимых социологических исследований. СПб. Режим доступа: http://www.cisr.pro/files/old/sbornik9/9_chekh.htm (accessed 6 September 2018). 
Тараканов Д. (2007) Дачные поселки Подмосковья в конце XIX - начале XX века: автореф. дис. ... канд. ист. наук.

Шмерлина И. (2007) Свободное время - навязанное пространство жизни? // Социальная реальность. № 8. C. 6-31.

Amin A., Thrift N. (2000) Cities: Reimagining the Urban. Cambridge: Polity.

Balfe J.H. (1995) The Inheritance of Summer Houses and Cultural Identity // The American Sociologist. Vol. 26. No. 4. P. 29-40.

Berg P.G., Nycander G. (1997) Sustainable neighbourhoods - a qualitative model for resource management in communities // Landscape and Urban Planning. No. 39. P. 117-135.

Bochardt I. (2007) Seasonal leisure spaces: dachas in Western Siberia // Culture. P. 8-10.

Chaplin D. (1999) Consuming work/productive leisure: the consumption patterns of second home environments. Leisure Studies. Vol. 18. No. 1. P. 41-55.

Clarke S. et al. (2000) The Myth of the Urban Peasant. Work, Employment and Society. No. 14. P. 481-499.

Colantonio A., Dixon T. (2009) Measuring Socially Sustainable Urban Regeneration in Europe, Oxford Institute for Sustainable.

Dominanty Project (2012). FOMnibus Survey. Public Opinion Foundation. Режим доступа: http://fom.ru/ Rabota-i-dom/10432 (дата обращения: 06.09.2018).

Ekström K.M., Ekström M.P., Potapova M., Shanahan H. (2003) Changes in food provision in Russian households experiencing perestroika // International Journal of Consumer Studies. Vol. 27. No. 4. P. 294-301.

Galtz N. (2000) Other Spaces and Everyday Ones: Promise and limits of Foucault's heterotopia for the study of everyday life.

Gerry C.J., Li C.A. (2010) Consumption smoothing and vulnerability in Russia // Applied Economics. Vol. 42. No. 16. P. $1995-2007$.

Giddens A. (1999) Runaway World: How Globalization is Reshaping Our Lives. London.

Harrison J. (2013) A timeless place: the Ontario cottage. UBC Press.
Inglehart R., Wetzel C. (2008) Changing Mass Priorities: The Link between Modernization and Democracy // Perspective on politics. Vol. 8. No. 2. P. 551-567.

Levada Center (2017). Dacha i domashniye zagotovki [Dacha and home preparations]. Режим доступа: https://www.levada.ru/2017/10/25/16909/ (дата обращения: 06.09.2018). (in Russian)

Lovell S. (2002) Soviet Exurbia: Dachas in Postwar Russia. Socialist spaces: sites of Everyday life in Eastern Bloc / D. Crowley, S. Reid, E. Berg (eds). P. 105-120.

Lovell S. (2008) 'Summerfolk: A History of the Dacha, 1710-2000:' Moscow. Academicals Project.

Marsh M. (1988) Suburban Men and Masculine Domesticity, 1870-1915 // American Quarterly. Vol. 40. No. 2. P. $165-186$.

Matthews H., Limb M. (1999) Defining an Agenda for the Geography of Children // Progress in Human Geography. Vol. 23. No. 1. P. 61-90.

McReynolds L. (2003) Russia at Play: Leisure Activities at the End of the Tsarist Era. Ithaca, NY; L.: Cornell University Press.

Ries N. (2009) Potato Ontology: Surviving Postsocialism in Russia // Cultural Anthropology. Vol. 24. no. 2. P. 181-212.

Rose R., Tikhomirov E. (1993) Who Grows Food in Russia and Eastern Europe? // Post Soviet Geography. Vol. 34. No. 2. P. 111-126.

Southworth C. (2006) The Dacha Debate: Household Agriculture and Labor Markets in Post-Socialist Russia // Rural Sociology. Vol. 71. No. 3. P. 451-478.

Strebkov D., Shevchuk A. (2012) Electronic Self-Employment in Russia // Problems of Economic Transition. Vol. 55. No. 5. P. 76-97.

Struyk R.J., Angelici K. (1996) The Russian dacha phenomenon // Housing Studies. Vol. 11. No. 2. P. $233-$ 250.

Urry J. (2007) Mobilities. Cambridge: Polity.

Yin R.K. (2014) Case Study Research. Design and Methods. 5 ed. SAGE Publications.

Zavisca J. (2003) Contesting Capitalism at the PostSoviet Dacha: The Meaning of Food Cultivation for Urban // Slavic Review. Vol. 62. No. 4. P. 786-810. 